\title{
Synthesis of DNA and Poly(Adenosine Diphosphate Ribose) in Normal and Chronic Lymphocytic
} Leukemia Lymphocytes

\author{
Nathan A. Berger, Jessie W. Adams, Georgina W. Sikorski, and Shirley J. \\ Petzold, Hematology-Oncology Division, The Department of Medicine, \\ The Jewish Hospital of St. Louis, Washington University School of Medicine, \\ St. Louis, Missouri 63110 \\ William T. Shearer, Division of Allergy and Immunology, The Department of \\ Pediatrics, St. Louis Children's Hospital, Washington University School of \\ Medicine, St. Louis, Missouri 63110
}

\begin{abstract}
A B S T RACT Peripheral blood lymphocytes were isolated from 9 patients with chronic lymphocytic leukemia (CLL) and 12 normal control donors. The cells were assayed for synthesis of DNA and poly(adenosine diphosphate ribose) (poly[ADPR]) immediately after isolation and on successive days following their treatment with phytohemagglutinin (PHA). Two different techniques were used to measure DNA synthesis. In the standard technique, DNA synthesis was measured by incubating intact cells with $\left[{ }^{3} \mathrm{H}\right]$ deoxythymidine. In the new technique, the lymphocytes were first rendered permeable to nucleotides, then DNA synthesis was measured by incubating them with $\left[{ }^{3} \mathrm{H}\right]$ deoxythymidine triphosphate in the presence of deoxyATP, deoxyGTP, deoxyCTP, ATP, and $\mathrm{Mg}^{++}$. Both assays showed the anticipated rise in DNA synthesis after PHA stimulation of normal cells. PHA-stimulated lymphocytes from patients with CLL demonstrated low levels of DNA synthesis in both assay systems.
\end{abstract}

The initial levels of poly(ADPR) synthesis were greater in CLL lymphocytes than in normal cells. Studies with a T-cell-depleted population of normal cells showed the same activity for poly(ADPR) synthesis that was demonstrated by the original population of normal cells. PHA stimulation produced an increase in poly(ADPR) synthesis in both the normal and CLL cells. The increase in poly(ADPR) synthesis in normal cells was coincident with the increase in DNA synthesis. The increase in poly(ADPR) synthesis in the CLL

Dr. Berger is a Leukemia Society of America Scholar.

Received for publication 16 December 1977 and in revised form 9 March 1.978. cells was dissociated from the delayed and diminished increase in DNA synthesis. Thus, CLL cells have higher than normal initial levels of poly(ADPR) synthesis. Poly(ADPR) synthesis is dissociated from DNA synthesis in CLL cells whereas it varies directly with DNA synthesis in normal lymphocytes.

\section{INTRODUCTION}

Poly(adenosine diphosphate ribose) polymerase has been implicated in the regulation of eukaryotic DNA synthesis and structure (1-4). It has recently been reported that poly(adenosine diphosphate ribose) (poly[ADPR] $)^{1}$ synthesis was higher in the peripheral blood lymphocytes from one patient with chronic lymphocytic leukemia (CLL) than in the lymphocytes from a normal donor (5). CLL lymphocytes have already been characterized as having defective DNA synthesis as demonstrated by their diminished and delayed response to stimulation with phytohemagglutinin (6). If CLL cells are in fact characterized by high levels of poly(ADPR) synthesis, this might provide an important basis for investigating, understanding, and manipulating the growth characteristics of these cells. The present studies were initiated to determine whether CLL cells are characterized by high levels of poly(ADPR) synthesis and also to determine whether the synthesis of poly(ADPR) is affected by changes in DNA synthesis in normal and CLL lymphocytes.

\footnotetext{
${ }^{1}$ Abbreviations used in this paper: ADPR, adenosine diphosphate ribose; CLL, chronic lymphocytic leukemia; dThd, deoxythymidine; dTTP, deoxythymidine triphosphate; PHA, phytohemagglutinin; poly(ADPR), poly(adenosine diphosphate ribose).
} 
Although the synthesis, chemical and structural features of poly(ADPR) are the subject of a recent comprehensive review (1), a brief outline of these characteristics is presented here. Poly(ADPR) polymerase uses NAD as a substrate to synthesize the homopolymer, poly(ADPR). The enzyme cleaves the $\mathrm{N}$-glycosidic bond between the nicotinamide and ribose moieties to produce nicotinamide and adenosine diphosphoribose. The adenosine diphosphoribose moieties are joined by ribose to ribose linkages to form the homopolymer whose backbone is then composed of ribose to ribose linkages alternating with phosphodiester linkages. Poly(ADPR) can be distinguished from DNA and RNA by its unique pattern of susceptibility to nuclease cleavage. It is not affected by DNase or RNase but is degraded by venom phosphodiesterase (7).

In the present study, we used a permeable cell technique to evaluate DNA synthesis and poly(ADPR) synthesis in lymphocytes obtained from normal donors and patients with CLL. With this system, nucleotides such as NAD or deoxythymidine triphosphate (dTTP) can be supplied directly to the enzymes functioning inside the nucleus $(8-12)$. Thus the system offers the advantages of working with isolated nuclei in that radioactive substrates and other cofactors or inhibitors can be supplied directly to the nuclear enzymes. However, studies in the permeable cell system have an advantage over studies in isolated nuclei in that they provide a better approximation of the physiologic process of nucleic acid synthesis $(10,13)$.

\section{METHODS}

Materials. The sources for chemicals and tissue culture media have been outlined previously $(11,14)$. Leukoagglutinating phytohemagglutinin (PHA) was purified from PHA-P as previously described (15). 5-Methylnicotinamide was a gift from Dr. Koert Goerzon, Eli Lilly and Company, Indianapolis, Ind. Phosphonoacetic acid was a gift from Abbott Laboratories, North Chicago, Ill. Cytembena (sodium cis- $\beta$-4-methoxybenzoyl- $\beta$-bromoacrylate) (NSC 104801) and daunorubicin (NSC 82151) were obtained from the Drug Development Branch of the National Cancer Institute. [methyl ${ }^{3} \mathrm{H}$ ]Thymidine (sp act $\left.=2 \mathrm{Ci} / \mathrm{mmol}\right) ;\left[\right.$ methyl $\left.{ }^{3} \mathrm{H}\right]-$ thymidine 5 -triphosphate (sp act $=40-60 \mathrm{Ci} / \mathrm{mmol}$ ), nicotinamide adenine dinucleotide [adenine $=2,8-{ }^{3} \mathrm{H}$ ] ( $\mathrm{sp}$ act $=1-5 \mathrm{Ci} / \mathrm{mmol}$ ), and protosol were all purchased from $\mathrm{New}$ England Nuclear, Boston, Mass.

Cell preparation and culture. Fasting blood was obtained from 9 patients with CLL and from 12 normal controls who were taking no drugs. Lymphocytes were isolated by Ficoll-Hypaque gradient centrifugation as previously described (14). Preparations were examined after supravital staining with janus green and neutral red and contained between 93 and $100 \%$ lymphocytes (16).

Thymus-derived $(\mathrm{T})$ cells were enumerated by determining the ability of the purified lymphocytes to form rosettes with sheep erythrocytes according to the method of Wybran et al. (17). A lymphocyte with three or more bound sheep erythrocytes was counted as a rosetting cell. The percent and type of bone marrow-derived (B) cells in the purified lymphocyte preparations were determined by the method of Greaves (18) using fluoresceinated goat antisera with specificity for $\gamma-, \mu$, and $\alpha$-heavy chains of human immunoglobulins (Miles Laboratories, Inc., Elkhart, Ind.). Cells bearing the classical speckled pattern were scored as positive for surface immunoglobulins. 200 cells were counted for each determination. In the experiment indicated, lymphocyte preparations were depleted of $T$ cells by rosette formation with neuraminidase-pretreated sheep erythrocytes followed by centrifugation through a Ficoll-Hypaque gradient as previously described (19).

Purified lymphocytes were cultured at a final concentration of $1 \times 10^{6}$ cells $/ \mathrm{ml}$ in $\alpha$ modified Eagles medium supplemented with $10 \%$ heat-treated fetal calf serum, $50 \mathrm{U} / \mathrm{ml}$ penicillin, $50 \mu \mathrm{g} / \mathrm{ml}$ streptomycin, and $25 \mathrm{mM}$ Hepes buffered to a final pH of 7.2. 20-ml aliquots of cell suspension were grown in $75-\mathrm{cm}$ tissue culture flasks at $37^{\circ} \mathrm{C}$. Leukoagglutinating PHA was added to cultures at a final concentration of $1.7 \mu \mathrm{g} / \mathrm{ml}$ which was previously determined to produce maximum stimulation of DNA synthesis.

DNA synthesis in intact cells was measured by incubating $2-\mathrm{ml}$ aliquots of cell suspension with $1 \mu \mathrm{Ci}\left[{ }^{3} \mathrm{H}\right]$ deoxythymidine (dThd) at $37^{\circ} \mathrm{C}$ for $2 \mathrm{~h}$. Incorporation of radioactivity into trichloroacetic acid (TCA) precipitates was determined as described below.

Cell permeabilization was carried out as previously described (8) using a cold shock in a hypotonic buffer system. The lymphocyte suspensions were vortexed to break up clumps, and counts were performed in a hemocytometer. All subsequent manipulations were performed between $0^{\circ}$ and $4^{\circ} \mathrm{C}$. The cells were collected by centrifugation at $1,000 \mathrm{~g}$ for $10 \mathrm{~min}$. The cell pellets were suspended at $2 \times 10^{6}$ cells $/ \mathrm{ml}$ and incubated for $15 \mathrm{~min}$ in ice-cold permeabilizing buffer, $0.01 \mathrm{M}$ Tris/ $\mathrm{HCl}, \mathrm{pH} 7.8,1 \mathrm{mM}$ EDTA, $4 \mathrm{mM} \mathrm{MgCl}_{2}$, and 30 $\mathrm{mM}$ 2-mercaptoethanol. The cells were collected again by centrifugation at $1,000 \mathrm{~g}$ for $10 \mathrm{~min}$ and resuspended at $2.5 \times 10^{7}$ cell $\mathrm{s} / \mathrm{ml}$. At this point, microscopic examination revealed that the cells were in a monodisperse suspension. They were all permeable as demonstrated by uptake of trypan blue (20).

As previously described, the $3 \times$ concentrated reaction mixture used to measure DNA synthesis in the permeable cells contained 0.1 M Hepes pH 7.8, $0.02 \mathrm{M} \mathrm{MgCl}_{2}, 0.21 \mathrm{M}$ $\mathrm{NaCl}, 15 \mathrm{mM}$ ATP, $0.3 \mathrm{mM}$ deoxyATP (dATP), $0.3 \mathrm{mM}$ deoxy (dGTP), $0.3 \mathrm{mM}$ deoxyCTP, and $2.5 \mu \mathrm{M}\left[{ }^{3} \mathrm{H}\right] \mathrm{dTTP}$ $\left(45 \times 10^{6} \mathrm{dpm} / \mathrm{nmol}\right)(10)$. DNA synthesis was assayed by combining $50 \mu \mathrm{l}$ of the permeable cell suspension containing $1.25 \times 10^{6}$ cells with $25 \mu \mathrm{l}$ of reaction mix. It should be noted that the concentrations of each component in the final reaction is one-third of that given in the $3 \times$ reaction mix. The components were combined in an ice water bath and the reactions started by transferring tubes to a $37^{\circ} \mathrm{C}$ water bath. Reactions were incubated for $30 \mathrm{~min}$ and terminated by addition of an excess of cold $10 \%$ TCA, $2 \% \mathrm{Na}_{4} \mathrm{P}_{2} \mathrm{O}_{7}$. Precipitates were collected on Whatman $\mathrm{GF} / \mathrm{C}$ filter disks and washed five times with cold $10 \%$ TCA, $2 \% \mathrm{Na}_{4} \mathrm{P}_{2} \mathrm{O}_{7}$, twice with cold ethanol and then prepared for scintillation counting in toluene scintillation fluid (10). DNA synthesis reactions were performed in triplicate, results are presented as disintegrations per minute incorporated per $1.25 \times 10^{6}$ cells in reaction per $30 \mathrm{~min}$ incubation.

The $3 \times$ poly(ADPR) polymerase reaction mix contained 100 $\mathrm{mM}$ Tris/HCl $\mathrm{pH} 7.8,120 \mathrm{mM} \mathrm{MgCl}_{2}$, and $1 \mathrm{mM}\left[{ }^{3} \mathrm{H}\right] \mathrm{NAD}$ $\left(\mathrm{sp}\right.$ act $\left.=20 \times 10^{3} \mathrm{dpm} / \mathrm{nmol}\right)$ as previously described $(11,12)$. Each component of the reaction system is present at concentrations that were previously determined to be optimal for this system (11). The concentration of each component in the 
final reaction is one-third of that given in the $3 \times$ reaction mix. Basal levels of poly(ADPR) synthesis were assayed by combining $200 \mu \mathrm{l}$ of the permeable cell suspension containing $5 \times 10^{6}$ cells with $100 \mu \mathrm{l}$ of the reaction mix. The reaction system to measure maximal levels of poly(ADPR) synthesis contained the same components as above and was adjusted to a final concentration of $0.05 \%$ Triton X-100 and contained a total of $100 \mu \mathrm{g}$ of DNase I (11). Components were all combined in an ice-water bath and reactions started by transfering to a $30^{\circ} \mathrm{C}$ water bath. Incubations were terminated by adding an excess of $10 \%$ TCA, $2 \% \mathrm{Na}_{4} \mathrm{P}_{2} \mathrm{O}_{7}$. Precipitates were collected on $\mathrm{GF} / \mathrm{C}$ filters, washed five times with cold $10 \%$ TCA, $2 \%$ $\mathrm{Na}_{4} \mathrm{P}_{2} \mathrm{O}_{7}$, twice with cold $95 \%$ ethanol, then prepared for scintillation counting as previously described $(8,11,12)$. All reactions were carried out in triplicate, results are presented as disintegrations per minute incorporated per $5 \times 10^{6}$ cells in reactions per $30 \mathrm{~min}$ incubation.

The poly(ADPR) synthesis reaction measures all of the radioactive ADPR moieties incorporated into TCA precipitable form; this includes synthesis of poly(ADPR) as well as the oligo- and poly(ADPR) attached to nuclear proteins. It may, however, exclude small oligomers of poly(ADPR) that are not attached to other macromolecules and are therefore not included in the acid precipitate. Apparent differences in the rate of poly(ADPR) synthesis can be due to actual differences in the synthetic rate or due to variable rates of degradation by endogenous glycohydrolases. However degradation rates have no influence in the present assay system since we have demonstrated that at the concentrations of NAD present in this assay, NAD completely inhibits the degradative enzymes (11).

\section{RESULTS}

Synthesis of DNA and poly(ADPR) in permeable cells. Peripheral blood lymphocytes were prepared from normal human donors and stimulated with leukoagglutinating-PHA. On the 3rd day in culture, the cells were permeabilized and incubated in either the DNA synthesis system or the poly(ADPR) synthesis system as described in Methods. The reactions were stopped by boiling for $10 \mathrm{~min}$ and the macromolecular products synthesized in each of these systems were examined for their differential susceptibilities to nuclease degradation. Table I demonstrates that the product synthesized from $\left[{ }^{3} \mathrm{H}\right] \mathrm{dTTP}$ in the presence of dCTP, dGTP, dATP, and ATP was degraded by DNase and venom phosphodiesterase but not by RNase. This indicates that DNA was the product of the reaction. The material synthesized in the presence of $\left[{ }^{3} \mathrm{H}\right]$ NAD was degraded by venom phosphodiesterase but not by DNase or RNase, indicating that poly(ADPR) was the product synthesized in this reaction (7).

To confirm the specificity of each reaction system, several inhibitors with relative specificities for DNA synthesis or poly(ADPR) synthesis were examined for their abilities to inhibit the respective reactions. Nicotinamide, 5-methylnicotinamide, and thymidine all inhibit poly(ADPR) polymerase $(11,21)$. Table II demonstrates that each of these compounds caused marked and selective inhibition of poly(ADPR) syn-
TABLE I

Nuclease Treatment of Products from DNA Synthesis and Poly(ADPR) Synthesis Reactions in Permeabilized PHA-Stimulated Normal Human Lymphocytes

\begin{tabular}{|c|c|c|c|c|}
\hline \multirow[b]{3}{*}{ Treatment } & \multicolumn{4}{|c|}{$\begin{array}{l}\text { Radioactivity remaining in macromolecular } \\
\text { form after treatment of reaction product }\end{array}$} \\
\hline & \multicolumn{2}{|c|}{$\begin{array}{l}\text { Incorporated } \\
\text { from }\left[{ }^{3} \mathrm{H}\right] \mathrm{dTTP}\end{array}$} & \multicolumn{2}{|c|}{$\begin{array}{l}\text { Incorporated } \\
\text { from }\left[{ }^{3} \mathrm{H}\right] \text { NAD }\end{array}$} \\
\hline & dpm & $\%$ Control & dpm & $\%$ Control \\
\hline Control & 89,803 & 100 & 30,135 & 100 \\
\hline $\begin{array}{l}\text { DNAse, } 100 \mu \mathrm{g} \\
\quad(41.7 \mathrm{U}) / 0.3 \mathrm{ml} \\
\text { RNAse, } 100 \mu \mathrm{g}\end{array}$ & 5,644 & 6.1 & 34.033 & 112 \\
\hline $\begin{array}{c}(50 \mathrm{U}) / 0.3 \mathrm{ml} \\
\text { VPDase, }{ }^{*} 300 \mu \mathrm{g}\end{array}$ & 86,000 & 95.6 & 27,583 & 91.5 \\
\hline$(10 \mathrm{U}) / 0.3 \mathrm{ml}$ & 9,004 & 9.8 & 4,217 & 13.9 \\
\hline
\end{tabular}

Normal human lymphocytes at $5 \times 10^{5} / \mathrm{ml}$ were stimulated with PHA. After 3 days in culture, cells were permeabilized and incubated at a concentration of $1 \times 10^{7}$ cells $/ \mathrm{ml}$ in complete DNA synthesis mix containing $\left[{ }^{3} \mathrm{H}\right] \mathrm{dTTP}$ or in complete (ADPR) synthesis mix containing $\left[{ }^{3} \mathrm{H}\right]$ NAD. The reactions were incubated for $30 \mathrm{~min}$, then terminated by boiling for $10 \mathrm{~min}$. The boiled suspensions were sonicated, then $0.3-\mathrm{ml}$ aliquots were immediately removed and transferred to $10 \%$ TCA, $2 \% \mathrm{Na}_{4} \mathrm{P}_{2} \mathrm{O}_{7}$ to measure the incorporation into acidinsoluble material from $\left[{ }^{3} \mathrm{H}\right] \mathrm{dTTP}$ or $\left[{ }^{3} \mathrm{H}\right]$ NAD. $0.3-\mathrm{ml}$ aliquots were also removed to separate tubes and incubated for $20 \mathrm{~h}$ at $37^{\circ} \mathrm{C}$ with the indicated additions. After $24 \mathrm{~h}$, the remaining macromolecular material was precipitated with an excess of $10 \%$ TCA, $2 \% \mathrm{Na}_{4} \mathrm{P}_{2} \mathrm{O}_{7}$ and prepared for scintillation counting as described in Methods.

*VPDase, venom phosphodiesterase.

thesis in the permeabilized human lymphocytes. Cytosine arabinoside triphosphate, cytembena, and phosphonoacetate all inhibit DNA polymerase $(8,11,22-$ 24) and they all caused selective inhibition of the DNA synthesis assay in the permeable human lymphocytes. Daunomycin, which affects both DNA synthesis and poly(ADPR) synthesis (11) caused total inhibition of the DNA synthesis system and also caused marked inhibition of poly(ADPR) synthesis.

We have demonstrated that DNA synthesis in permeabilized cells represents continuation synthesis of the replication sites that were active in vivo just before the cells were permeabilized (10). In the reaction system described above, the permeable cells are supplied with all the known small molecular weight components and cofactors required for DNA synthesis (8). The assay therefore depends on having active DNA polymerase associated with an active DNA template provided by the cell. The measurement may also be influenced by many of the other enzymes associated with the replication fork (25). This complex process measured in permeable cells has therefore 
been termed the DNA replication complex to differentiate it from a strict measurement of DNA polymerase (26). The activity of the DNA replication complex measured in the permeable cells will be referred to as DNA replicase throughout the rest of this paper.

We compared the use of $\left[{ }^{3} \mathrm{H}\right] \mathrm{dTh}$ incorporation with the DNA replicase assay to measure DNA synthesis in control and PHA-stimulated normal human lymphocytes. The unstimulated cells maintained a low level of thymidine incorporation and a low level of DNA replicase activity. PHA-stimulated cells demonstrated a characteristic increase in replicative DNA synthesis. All of the lymphocyte cultures that showed an increase in $\left[{ }^{3} \mathrm{H}\right] \mathrm{d}$ Thd incorporation also showed a concomitant increase in activity of DNA replicase.

In studying poly(ADPR) synthesis in several other cell types, we found that treatment of the cells with DNase increased the activity of poly(ADPR) polymerase (11). Fig. 1 shows the effect of adding DNase I to nucleotide-permeable human lymphocytes. As previously noted with $\mathrm{L}$ cells (11), the rates of poly(ADPR) synthesis increased with increasing concentrations of DNase until saturating levels of DNase were achieved. Both control and PHA-treated lympho-

TABLE II

Comparison of Agents Affecting DNA Synthesis and Poly(ADPR) Synthesis in Permeable PHAStimulated Human Lymphocytes

\begin{tabular}{lcc}
\hline \multirow{2}{*}{ Condition } & \multicolumn{2}{c}{ Activity, \% of control } \\
\cline { 2 - 3 } & DNA & poly(ADPR) \\
\hline Control & 100 & 100 \\
$10 \mathrm{mM}$ Nicotinamide & 98.3 & 4.9 \\
$10 \mathrm{mM} 5-\mathrm{CH}_{3}$-Nicotinamide & 88.6 & 8.8 \\
$10 \mathrm{mM}$ Thymidine & 88 & 5.2 \\
1 mM Cytosine arabinoside & & \\
triphosphate & 33.4 & 91.9 \\
$10 \mathrm{mM}$ Cytembena & 26.8 & 99.5 \\
10 mM Phosphonoacetate & 12.1 & 92.7 \\
$1 \mathrm{mM}$ Daunomycin & 1.2 & 37.6 \\
\hline
\end{tabular}

Normal human lymphocytes were stimulated with PHA. On the 3rd day of incubation, the cells were permeabilized and assayed for activity of DNA replicase and poly(ADPR) polymerase as outlined in Methods. Inhibitors were prepared in $50 \mathrm{mM}$ Tris/ $\mathrm{HCl}$ at a final $\mathrm{pH}$ of 7.8 and were added to the reaction components just before addition of the cells. The concentration of the inhibitor in the table was the final concentration of the inhibitor in the complete reaction system. DNA synthesis reactions were incubated at $37^{\circ} \mathrm{C}$, poly(ADPR) reactions at $30^{\circ} \mathrm{C}$. All incubations were for 30 min. The results are averages of individual experiments performed with lymphocytes from three different donors. The amounts of polymers synthesized in the presence of the inhibitors are expressed as a percentage of the amount synthesized in simultaneously performed untreated controls.

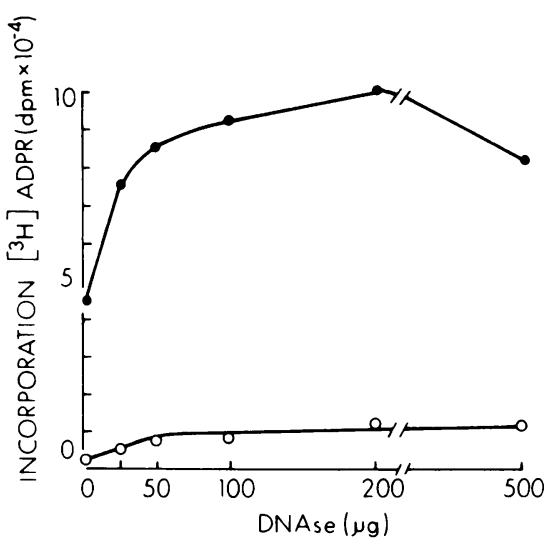

Figure 1 Effect of added DNAse on synthesis of poly(ADPR). Peripheral blood lymphocytes were prepared from normal donors and maintained in tissue culture in the presence or absence of PHA as described in Methods. After 3 days in culture, control and PHA-stimulated cells were permeabilized and aliquots were assayed for poly(ADPR) synthesis activity in the presence of increasing concentrations of added DNAse as described in Methods. Each reaction contained $5 \times 10^{6}$ permeable lymphocytes and was incubated for $30 \mathrm{~min}$ at $30^{\circ} \mathrm{C}$. Control lymphocytes (O); PHA-stimulated lymphocytes (O).

cytes reached their maximum levels of poly(ADPR) synthesis at about the same concentrations of added DNase. At saturating concentrations of DNase, the maximum activity of poly(ADPR) polymerase was much greater in the PHA-treated cells than in the untreated cells. This observation forms the basis for two measurements of poly(ADPR) synthesis in the permeable cells. The basal activity was measured directly by supplying $\left[{ }^{3} \mathrm{H}\right] \mathrm{NAD}$ to permeable cells. The DNase-responsive activity was measured by supplying $\left[{ }^{3} \mathrm{H}\right] \mathrm{NAD}$ to permeable cells in the presence of saturating amounts of added DNase.

Characteristics of DNA synthesis and poly(ADPR) synthesis in normal and CLL lymphocytes. The lymphocyte preparations from normal donors and CLL patients were analyzed to determine the percentage of $\mathrm{T}$ and B cells. Lymphocytes prepared from normal donors contained $50-78 \% \mathrm{~T}$ cells as determined by sheep rosettes. All of the patients with CLL showed the anticipated decrease in T cells (27); the lymphocytes prepared from these patients contained $1-30 \% \mathrm{~T}$ cells. Two of the patients with CLL had high levels of $\mathrm{B}$ cells demonstrated by surface immunoglobulin studies. Five of the patients with CLL did not have increased numbers of lymphocytes with surface immunoglobulins detectable by immunofluorescence measurements. It is possible that these represent the subset of CLL patients whose malignant B cells, containing $\mathrm{Fc}$ or $\mathrm{C} 3$ receptors, can only be detected by the more sensitive methods of binding of fluoresceinated, heat-aggregated human IgG or forming rosettes 

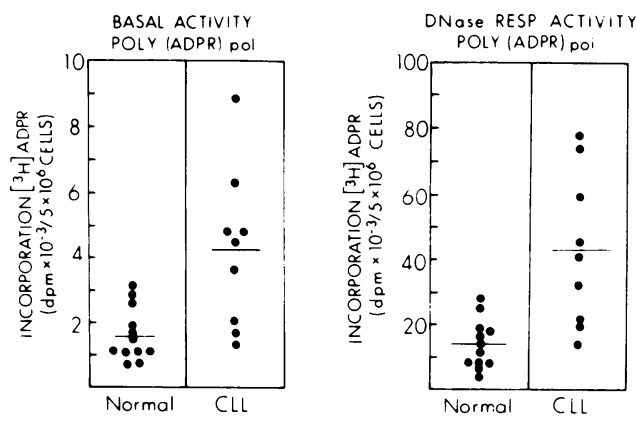

Figure 2 Comparison of basal and DNase-responsive activities of poly(ADPR) polymerase in lymphocytes from normal donors and patients with CLL. Peripheral blood lymphocytes were isolated from 12 normal donors and 9 patients with CLL. The data in these figures were obtained immediately after the cells were isolated. The cells were permeabilized and assayed for poly(ADPR) synthesis as described in Methods. The assay to measure stimulated activity of poly(ADPR) polymerase contained $100 \mu \mathrm{g}$ DNAse, the assays to measure the basal activity contained no DNAse. Each reaction contained $5 \times 10^{6}$ permeable lymphocytes and each point represents the mean of triplicate assays. The horizontal line in each panel represents the mean value for all donors.

with complement-coated sheep erythrocytes, respectively (28). Only one patient had received a cytotoxic agent in the 3 mo preceding this study. Two patients had been receiving prednisone for $2 \mathrm{wk}$ before the lymphocytes were prepared.

The rates of DNA synthesis measured in lymphocytes immediately after isolation from peripheral blood were low as determined both by $\left[{ }^{3} \mathrm{H}\right] \mathrm{dTh}$ incorporation and by the DNA replicase assay. The rates of DNA synthesis were within the same range for both the normal and CLL cells. As shown in Fig. 2, the mean basal level of poly(ADPR) synthesis in the CLL cells was 2.5 times as high as the activity in the normal cells. In addition, the range of variation in the CLL cells was much greater than in the normal cells. The mean DNase-responsive activity of poly(ADPR) polymerase in the CLL cells was 2.9 times as high as the activity in the normal cells. Although there was considerable overlap between the normal and CLL cells, it is clear that some of the CLL patients had levels for basal and DNase-responsive poly(ADPR) synthesis that were far in excess of the normal range. There was no relation between the rates of poly(ADPR) synthesis and the absolute lymphocyte concentration in the peripheral blood, the histories of drug exposure or the age of the donors.

Preliminary studies were performed to determine whether the higher levels of poly(ADPR) synthesis in the CLL lymphocytes were due to their relative differences in $\mathrm{T}$ - and B-cell content. Lymphocytes were prepared from a normal donor and depleted of $\mathrm{T}$ cells by incubation with neuraminidase-treated sheep erythrocytes (19). Before adsorption the total lymphocyte population contained $50 \%$ sheep rosetting cells. After adsorption the lymphocyte preparation contained only $12 \%$ sheep rosetting cells. The levels of poly(ADPR) and DNA synthesis in the total and T-celldepleted populations were identical. Thus, it is improbable that the differences between normal and CLL patients were due to the relative differences in $\mathrm{T}$ - or B-cell content.

Lymphocytes from normal donors showed their peak DNA synthesis on the 3rd or 4th day after PHA stimulation. Cells from most of the patients with CLL showed a small increase in DNA synthesis in response to PHA stimulation. As previously reported, the peak of $\left[{ }^{3} \mathrm{H}\right] \mathrm{dThd}$ incorporation by CLL cells was lower and occurred later than those demonstrated by the normal cells (6). The peaks of DNA replicase activity were also decreased and delayed when compared to those of normal lymphocytes. This demonstrates that the decrease of DNA synthesis observed in CLL cells is not simply due to disorders in synthesis of DNA precursors or cofactors but actually represents decreased activity of the DNA replication machinery.

The rates of poly(ADPR) synthesis were also affected by PHA treatment. Lymphocytes from normal donors showed an increase in both basal and DNase-responsive activities of poly(ADPR) polymerase. In general the activities reached their maximum at about the same time as DNA synthesis. The CLL cells showed a variable response in poly(ADPR) synthesis. However, most showed an early increase in activity similar to the normal cells but then showed a slight delay in reaching peak activity. The highest values achieved for the basal and DNase-responsive activities of poly(ADPR) polymerase were in the same range in the PHA-treated CLL and normal cells despite the great variations in their initial levels of activity.

Fig. 3 presents some representative samples of the time-courses of the responses of DNA synthesis and poly(ADPR) synthesis by lymphocytes from normal donors and from several patients with CLL. Panel A shows the response of a normal donor in which there was an increase in DNA synthesis measured by both $\left[{ }^{3} \mathrm{H}\right] \mathrm{dThd}$ incorporation and by the DNA replicase assay. After the peak on day 3 and 4, these two measurements of DNA synthesis decreased concurrently. In the normal lymphocytes, the basal and DNase-responsive activities of poly(ADPR) polymerase increased and decreased concurrently with the changes in DNA synthesis. Several different patterns of enzyme activity were demonstrated by the cells from the CLL patients. In the patients' lymphocytes presented in panel $\mathrm{B}$, there was essentially no increase in DNA synthesis measured by $\left[{ }^{3} \mathrm{H}\right] \mathrm{d}$ Thd incorporation or by the DNA replicase assay. There was however, an increase in the DNase-responsive poly(ADPR) poly- 


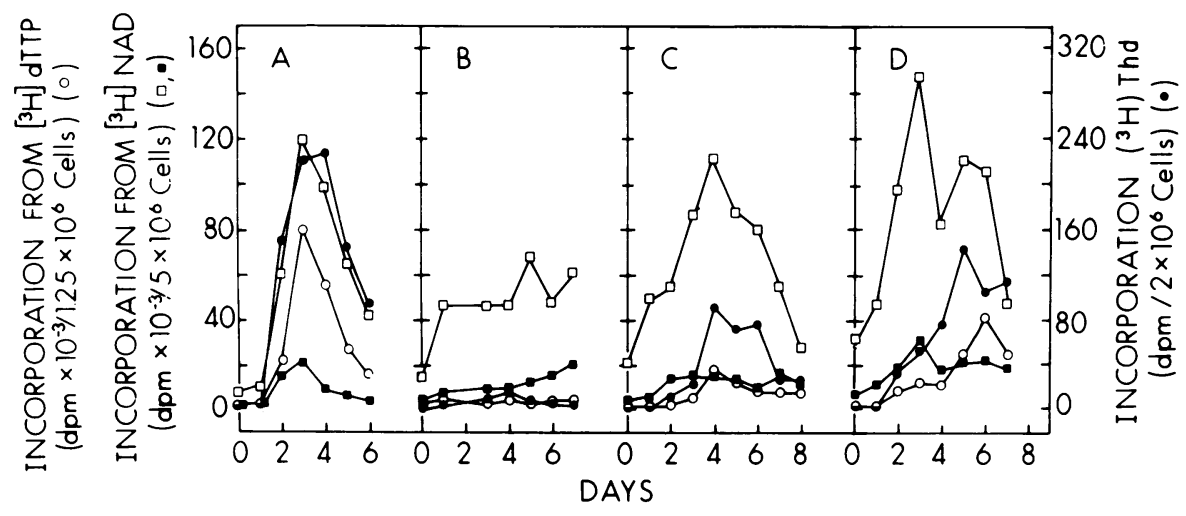

FIGURE 3 Synthesis of DNA and poly(ADPR) in peripheral blood lymphocytes from normal human donors and from patients with CLL. Lymphocytes were isolated from peripheral blood, stimulated with leukoagglutinating PHA and maintained in tissue culture as described in Methods. Immediately after isolation and on each successive day, aliquots of lymphocytes were removed and assayed for $\left[{ }^{3} \mathrm{H}\right] \mathrm{dTh}$ incorporation. Aliquots were also permeabilized and incubated with the appropriate reaction mixes described in Methods to measure DNA replicase or poly(ADPR) synthesis. Assays of $\left[{ }^{3} \mathrm{H}\right] \mathrm{dTh}$ Th incorporation contained $2 \times 10^{6}$ intact lymphocytes and were incubated for $2 \mathrm{~h}$ at $37^{\circ} \mathrm{C}(0)$. The assays for DNA replicase $(O)$ measured the incorporation from $\left[{ }^{3} \mathrm{H}\right] \mathrm{dTTP}$; each assay contained $1.25 \times 10^{6}$ cells and was incubated for $30 \mathrm{~min}$ at $37^{\circ} \mathrm{C}$. The assays for poly(ADPR) synthesis measured the incorporation from $\left[{ }^{3} \mathrm{H}\right] \mathrm{NAD}$; each assay contained $5 \times 10^{6}$ cells and was incubated for $30 \mathrm{~min}$ at $30^{\circ} \mathrm{C}$. The stimulated or total activity of poly(ADPR) synthesis was measured in permeable cells in the presence of $100 \mu \mathrm{g}$ DNase ( $\square)$. The basal activity of poly(ADPR) synthesis was measured in the permeable cells in the absence of added DNase ( $\mathbf{\square}$. Lymphocytes in panel A from normal donor 3, in panel B from CLL patient 3 , in panel C from CLL patient 1 and in panel D from CLL patient 8.

merase activity and a delayed increase in the basal level of poly(ADPR) synthesis. This demonstrates that the PHA-stimulated rise in poly(ADPR) synthesis can be dissociated from DNA synthesis. In the patients' cells presented in panels $\mathrm{C}$ and $\mathrm{D}$, there were delayed increases in DNA synthesis measured by both $\left[{ }^{3} \mathrm{H}\right]-$ dThd incorporation and by the DNA replicase assay. The cells from both of these patients showed an early increase in poly(ADPR) polymerase activity, again demonstrating that synthesis of poly(ADPR) can be dissociated from DNA synthesis.

\section{DISCUSSION}

The present study demonstrates that the increase in lymphocyte DNA synthesis associated with mitogen stimulation can be measured by the DNA replicase assay in permeable cells. Using the same technique, Buckley and Wedner (29) have now shown that permeable lymphocytes carry out semi-conservative replicative synthesis of high molecular weight DNA. Thus our earlier observation that the permeable cell technique can be used to study replicative DNA synthesis in $L$ cells $(8-10)$ can now be extended to human lymphocytes.

Poly(ADPR) synthesis was examined in the permeable cells in the absence and presence of added DNase. Stimulation of poly(ADPR) synthesis by DNase has previously been noted by Miller (30) in HeLa cell nuclei and by us (11) in permeable L cells. Addition of DNase to permeable cells under these conditions results in prompt degradation of the cell DNA (9). Since other agents and processes that damage DNA also cause prompt increases in poly(ADPR) synthesis (31, 32 ) it is probable that the increase in poly(ADPR) synthesis due to DNase treatment is due to the accompanying DNA damage. While the precise mechanism of this increase remains to be determined, it provides a useful technique to measure stimulated levels of poly(ADPR) synthesis. Although there is no direct proof, it is possible that the assay for DNaseresponsive poly(ADPR) polymerase activity, measures the total available enzyme in the cell; whereas the assay of the basal activity measures the physiologic activity of the enzyme at the time that the cells were permeabilized $(11,12)$.

Both the basal and DNase-responsive poly(ADPR) synthesis were low in freshly prepared normal human lymphocytes. Stimulation of normal cells with PHA caused the basal and DNase-responsive levels of poly(ADPR) synthesis to increase and decrease concurrently with the rise and fall in the activity of the DNA replicase system. This is similar to the observation by Lehmann et al. (33) that the activity of poly(ADPR) polymerase increased along with the increase in DNA synthesis in PHA-stimulated pig lymphocytes. 
However, this is opposite to our recent findings in L cells where the basal activity of poly(ADPR) synthesis was low when DNA synthesis was high and conversely the basal activity of poly(ADPR) synthesis was high when DNA synthesis was stopped or suppressed $(11,12)$.

When compared to normal lymphocytes, the freshly isolated CLL cells had higher initial activities of basal and DNase-responsive poly(ADPR) synthesis. This confirms the observation of Burzio et al. (5) that nuclei isolated from the lymphocytes of one patient with CLL had higher levels of poly(ADPR) synthesis than were found in nuclei from a normal donor. In the present study, when the CLL lymphocytes were stimulated with PHA, the cells from most of the patients demonstrated an increase in poly(ADPR) synthesis. They reached levels of activity similar to those attained in normal cells. The increase in poly(ADPR) synthesis in the CLL lymphocytes usually occurred in the first few days after lymphocyte stimulation and was dissociated from the impaired rise in DNA synthesis which usually occurred after 4-5 days in culture. This dissociation of poly(ADPR) synthesis and DNA synthesis demonstrates that the stimulation of poly(ADPR) synthesis does not require new DNA synthesis to occur first. It appears rather that poly(ADPR) synthesis can be stimulated before and possibly separate from DNA synthesis. This is consistent with the results of Lehmann et al. (33) who found that the use of actinomycin to inhibit DNA synthesis in PHA-stimulated pig lymphocytes did not prevent the increase in poly(ADPR) synthesis.

The high levels of poly(ADPR) polymerase detected in the CLL cells can be added to a number of other disorders of enzyme activities that have been reported in this disease. For example, DNA synthesis (6), adenosine deaminase (34), thymidine kinase (35), glucose-6-phosphate dehydrogenase, 6-phosphonogluconate dehydrogenase (36), 5'-nucleotidase (37, 38), and ribosome function (39) are all deficient in CLL lymphocytes.

In all these cases, the enzyme activities have been found to be low, whereas the activity of poly(ADPR) polymerase in CLL cells is high. High activity of poly(ADPR) polymerase has been associated with cells traversing the cell cycle and with cells in which the DNA has been damaged $(1,11,32)$. Thus it is possible that the high activity of poly(ADPR) polymerase indicates that some of the peripheral blood lymphocytes in CLL are actually immature proliferating cells (i.e., in the cell cycle rather than in $G_{0}$ ). An alternative possibility is that the high levels of poly(ADPR) polymerase in CLL cells reflects the presence of damaged or disordered DNA. This would be consistent with the resemblance of CLL lymphocytes to actinomycin-treated pig lymphocytes in terms of their synthesis of DNA and poly(ADPR) in response to PHA stimulation (33). This possibility might also explain the poor response of CLL cells to mitogenic stimulation, since DNA damage in general produces delays in replicative DNA synthesis and prolongs the time required to traverse the cell cycle (40-43). Further studies are indicated on the role of poly(ADPR) synthesis and the integrity of the DNA in normal and CLL cells since they may provide new information on the disordered DNA synthesis associated with CLL. Moreover, since there are many well-characterized inhibitors for poly(ADPR) polymerase, the high activity of this enzyme in CLL cells may represent a fruitful area for investigations of therapeutic intervention.

\section{ACKNOWLEDGMENTS}

We thank Mr. Hal Mettes for his excellent technical assistance; Dr. K. Gerzon, Eli Lilly and Company for the 5methylnicotinamide and Dr. A. O. Geizzler, Abbott Laboratories for the phosphonoacetate. We also thank Dr. P. J. Buckley and Dr. H. J. Wedner for a preprint of their manuscript.

This work was supported, in part, by grants from the National Leukemia Association, Inc., Garden City, N. Y.; The Jewish Hospital of St. Louis; grant IM-54A from the American Cancer Society; U. S. Public Health Service Grant NIH 5 RO1 CA16391 and an American Cancer Society Faculty Research Award to Dr. Shearer.

\section{REFERENCES}

1. Hayaishi, O., and K. Ueda. 1977. Poly (ADPRibose) and ADP-ribosylation of proteins. Annu. Rev. Biochem. 46: 95-116.

2. Burzio, L., and S. S. Koide. 1970. A functional role of poly ADPR in DNA synthesis. Biochem. Biophys. Res. Commun. 40: 1013-1020.

3. Nishizuka, Y., K. Ueda, K. Yoshihara, H. Yamamura, M. Takoda, and O. Hayaishi. 1969. Enzymic adenosine diphosphoribosylation of nuclear proteins. Cold Spring Harbor Symp. Quant. Biol. 34: 781-786.

4. Brightwell, M. D., C. E. Leech, M. K. O'Farrell, W. J. D. Whish, and S. Shall. 1975. Poly (adenosine diphosphate ribose) polymerase in physarum polycephalum. Biochem. J. 147: 119-129.

5. Burzio, L, L. Reich, and S. S. Koide. 1975. Poly (adenosine diphosphoribose) synthesis activity of isolated nuclei of normal and leukemic leukocytes. Proc. Soc. Exp. Biol. Med. 149: 933-938.

6. Havemann, K., and A. D. Rubin. 1968. The delayed response of chronic lymphocytic leukemia lymphocytes to phytohemagglutinin in vitro. Proc. Soc. Exp. Biol. Med. 127: 668-671.

7. Nishizuka, Y., K. Ueda, K. Nakazawa, and O. Hayaishi. 1967. Studies on the polymer of adenosine diphosphate ribose I enzymatic formation from nicotinamide adenine dinucleotide in mammalian nuclei. J. Biol. Chem. 242: 3164-3171.

8. Berger, N. A., and E. S. Johnson. 1976. DNA synthesis in permeabilized mouse L cells. Biochim. Biophys. Acta. 425: $1-17$.

9. Berger, N. A., W. P. Erickson, and G. Weber. 1976. Histone inhibition of DNA synthesis in eukaryotic cells 
permeable to macromolecules. Biochim. Biophys. Acta. 447: $65-75$.

10. Berger, N. A., S. J. Petzold, and E. S. Johnson. 1977. High molecular weight DNA intermediates synthesized by permeabilized L cells. Biochim. Biophys. Acta. 478: $44-58$.

11. Berger, N. A., G. Weber, and A. S. Kaichi. 1978. Characterization and comparison of poly (adenosine diphospho ribose) synthesis and DNA synthesis in nucleotide permeable cells. Biochim. Biophys. Acta. In press.

12. Berger, N. A., G. Weber, A. S. Kaichi, and S. J. Petzold. 1978. Relation of poly (ADPR) synthesis to DNA synthesis and cell growth. Biochim. Biophys. Acta. In Press.

13. Tseng, B. Y., and M. Goulian. 1975.. DNA synthesis in human lymphocytes: intermediates in DNA synthesis, in vitro and in vivo. J. Mol. Biol. 99: 317-337.

14. Mendelsohn, J., S. A. Skinner, and S. Kornfeld. 1971. The rapid induction by phytohemagglutinin of increased $\alpha$ aminoisobutyric acid uptake by lymphocytes. J. Clin. Invest. 50: 818-826.

15. Kornfeld, R., W. T. Gregory, and S. A. Kornfeld. 1972. Red kidney bean (Phaseolus vulgaris) Phytohemagglutinin. Methods Enzymol. 28: 344-349.

16. Cunningham, R. S., and E. H. Tompkins. 1930. The supravital staining of normal human blood cells. Folia Haematol. (Leipz). 42: 257-270.

17. Wybran, J., M. C. Carr, and H. H. Fudenberg. 1972. The human rosette-forming cell as marker of a population of thymus-derived cells. J. Clin. Invest. 51: 2537-2543.

18. Greaves, M. F. 1970. Biological effects of anti-immunoglobulins. Evidence for immunoglobulin receptors on "T" and "B" lymphocytes. Transplant Rev. 5: 45-75.

19. Lohrmann, H.-P., L. Novikovs, and R. G. Graw, Jr. 1974. Cellular interactions in the proliferative response of human $\mathrm{T}$ and $\mathrm{B}$ lymphocytes to phytomitogens and allogeneic lymphocytes. J. Exp. Med. 139: 1553-1565.

20. Boyse, E. A., L. J. Old, and I. Chouroulinkov. 1964. Cytotoxic test for demonstration of mouse antibody. Methods Med. Res. 10: 39-47.

21. Preiss, J., R. Schlaeger, and H. Hilz. 1971. Specific inhibition of poly ADPRibose polymerase by thymidine and nicotinamide in HeLa cells. FEBS (Fed. Eur. Biochem. Soc.) Lett. 19: 244-246.

22. Graham, F. L., and G. F. Whitmore. 1970. Studies in mouse L-cells on the incorporation of $1-\beta$-D-arabinofuranosyl cytosine into DNA and on inhibition of DNA polymerase by $1-\beta$-D-arabinosyl cytosine $5^{\prime}$-triphosphate. Cancer Res. 30: 2636-2644.

23. Berger, N. A., and G. Weber. 1977. Description of a permeable eukaryotic cell system to study agents affecting DNA synthesis: demonstration that cytembena is a direct inhibitor of replicative DNA synthesis. $J$. Natl. Cancer Inst. 58: 1167-1169.

24. Leinbach, S. S., J. M. Reno, L. F. Lee, A. F. Isbell, and J. I. Boezi. 1976. Mechanism of phosphonoacetate inhibition of herpes virus-induced DNA polymerase. Biochemistry 15: 426-430.

25. Alberts, B., and R. Sternglanz. 1977. Recent excitement in the DNA replication problem. Nature (Lond.) 269: $655-661$.

26. Seki, S., M. LeMahieu, and G. C. Mueller. 1975. A permeable cell system for studying DNA replication in synchronized HeLa cells. Biochim. Biophys. Acta. 378: 333-343.
27. Piessens, W. F., P. H. Schur, W. C. Maloney, and W. H. Churchill. 1973. Lymphocyte surface immunoglobulins, distribution and frequency in lymphoproliferative diseases. N. Engl. J. Med. 288: 176-180.

28. Bentwich, Z., A. Pollack, and S. D. Douglas. 1976. Surface Markers and Other Characteristics of the Lymphocyte in Chronic Lymphocytic Leukemia in Immunological Parameters of Host-Tumor Relationships. D. W. Weiss editor. Academic Press, Inc., New York. 24-44.

29. Buckley, P. J., and H. J. Wedner. 1978. Measurement of the DNA synthetic capacity of activated lymphocytes: nucleotide triphosphate incorporation by permeabilized cells. J. Immunol. In press..

30. Miller, E. G. 1975. Stimulation of nuclear poly (adenosine diphosphate ribose) polymerase activity from HeLa cells by endonucleases. Biochim. Biophys. Acta. 395: 191-200.

31. Miller, E. G. 1976. Stimulation of poly (adenosine diphosphate ribose) polymerase activity by bleomycin. Fed. Proc. 36: 906. (Abstr.)

32. Davies, M. J., S. Shall, and C. J. Skidmore. 1977. Poly (adenosine diphosphate ribose) polymerase and deoxyribonucleic acid damage. Biochem. Soc. Trans. 5: 949950.

33. Lehmann, A. R., S. Kirk-Bell, and S. Shall. 1974. The relationship between cell growth, macromolecular synthesis and poly ADP-ribose polymerase in lymphoid cells. Exp. Cell Res. 83: 63-72.

34. Turg, R., R. Silber, F. Quagliata, M. Conklyn, J. Gottesman, and R. Hirschhorn. 1976. Adenosine deaminase activity in chronic lymphocytic leukemia.J. Clin. Invest. 57: 756-761.

35. Rabinowitz, Y., P. Wong, and B. A. Wilhite. 1970. Effect of phytohemagglutinin on enzymes of thymidine salvage pathway of cultured chronic lymphatic leukemia lymphocytes. Blood. 35: 236-242.

36. Brody, J. I., F. A. Oski, and D. E. Singer. 1969. Impaired pentose phosphate shunt and decreased glycolytic activity in lymphocytes of chronic lymphocytic leukemia. Metabolic pathway . . . ? Blood. 34: 421-429.

37. Quagliata, F., D. Faig, M. Conklyn, and R. Silber. 1974. Studies on the lymphocyte 5 -nucleotidase in chronic lymphocytic leukemia, infectious mononucleosis, normal subpopulations and phytohemagglutinin-stimulated cells. Cancer Res. 34: 3197-3202.

38. Silber, R., M. Conklyn, G. Grusky, and D. ZuckerFranklin. 1975. Human lymphocytes: 5'-nucleotidasepositive and negative subpopulations. J. Clin. Invest. 56: $1324-1327$.

39. Ramsey, R. L., and J. E. Ultmann. 1972. Protein synthesis by ribosomes from blood lymphocytes of normal and patients with chronic lymphocytic leukemia. Proc. Soc. Exp. Biol. Med. 141: 839-841.

40. Mak, S., and J. E. Till. 1963. The effects of X-rays on the progress of L-cells through the cell cycle. Radiat. Res. 20: 600-618.

41. Makino, F., and S. Okada. 1975. Effects of ionizing radiations on DNA replication in cultured mammalian cells. Radiat. Res. 62: 39-51.

42. Griffiths, T. D., and L. J. Tolmach. 1975. Age-dependence of the X-ray-induced deficiency in DNA synthesis in HeLa S3 cells during generation I. Radiat. Res. 63: $501-520$.

43. Bhuyan, B. K., L. G. Scheidt, and T. J. Fraser. 1972. Cell cycle phase specificity of antitumor agents. Cancer Res. 32: 398-407. 